\title{
Effect of Different Cryoprotectants and Sperm Densities of Orange Mud Crab, Scylla olivacea (Herbst, 1796) for Long-Term Storage of Spermatozoa \\ (Kesan Perbezaan Kepadatan Sperma dan Krioprotektan ke atas Penyimpanan Jangka Panjang Spermatozoa Ketam Bakau, Scylla olivacea (Herbst, 1796))
}

\author{
Mhd IkHwanuddin*, Teng Phei Yin, Abdul Jabbar Menon, Safiah Jasmani \& Ambok Bolong Abol-Munafi
}

\begin{abstract}
The objectives of this study were to determine the effect of different cryoprotectants and sperm densities for longterm storage of orange mud crab, Scylla olivacea spermatozoa. Spermatozoa were obtained by homogenizing the spermatophores using a glass homogenizer in an ice-bath followed by centrifugation at $4^{\circ} \mathrm{C}$. Spermatozoa were then suspended in calcium-free saline (Ca-F saline) containing 5\% of the following cryoprotectants: Glycerol, dimethyl sulfoxide (DMSO) and methanol. Sperm which vibrated and rotated were counted as live during sperm viability assessment. Samples of spermatozoa were cooled to $-196^{\circ} \mathrm{C}$ by two-step freezing, first to $-80^{\circ} \mathrm{C}$ and then by plunging into liquid nitrogen (LN). Spermatozoa were gradually cooled at $1^{\circ} \mathrm{C} / \mathrm{min}$. Thawing was carried out in a $30^{\circ} \mathrm{C}$ water bath for 2 min. This yielded live sperm after storage in LN for 30 days. The best sperm viability was obtained from a density of $10^{8}$ cells per $m L$ in DMSO. There was no significant difference ( $\mathrm{p}>0.05)$ among cryoprotectants toward sperm viability. However, sperm viability was significantly affected $(\mathrm{p}>0.05)$ by cell densities. In conclusion, DMSO gave the best protection to sperm cells of $\mathrm{S}$. olivacea, but the effectiveness of DMSO as a cryoprotectant is influenced by sperm density.
\end{abstract}

Keywords: Cryprotectants; orange mud crab; Scylla olivacea; sperm density; spermatozoa

\section{ABSTRAK}

Objektif kajian ini adalah untuk menentukan kesan krioprotektan dan kepadatan sperma untuk penyimpanan jangka panjang spermatozoa ketam bakau, Scylla olivacea. Spermatozoa diperoleh daripada proses penghomogenan spermatofor menggunakan kaca penghomogenan di dalam takungan yang berisi ais dan diikuti dengan proses penapisan pada suhu $4^{\circ} \mathrm{C}$. Kemudian, spermatozoa dicampurkan dengan salin bebas-kalsium (Ca-F saline) yang mengandungi gliserol krayoprotektan, dimetil sulfoksida (DMSO) dan metanol masing-masing pada kepekatan 5\%. Sperma yang bergegar dan berputar akan dikira sebagai sperma yang hidup di dalam penilaian kemajuan sperma. Sampel spermatozoa kemudiannya disejukkan pada suhu $-196^{\circ} \mathrm{C}$ melalui dua langkah pembekuan, pertama pada suhu $-80^{\circ} \mathrm{C}$ dan kemudian dimasukkan ke dalam cecair nitrogen (LN). Penyejukkan secara beransur-ansur pada $1^{\circ} \mathrm{C} /$ min telah dijalankan dengan menyejukkan spermatozoa tersebut. Pencairan dilakukan pada suhu $30^{\circ} \mathrm{C}$ di dalam bekas takungan berisi air selama 2 min. Ini menghasilkan sperma yang hidup di dalam simpanan LN selama 30 hari. Kemajuan sperma yang terbaik diperoleh daripada kepadatan $10^{8}$ sel per $m L$ di dalam DMSO. Tiada perbezaan yang ketara $(\mathrm{p}>0.05)$ antara krioprotektan dan kemajuan sperma. Walau bagaimanapun, terdapat perbezaan yang ketara $(\mathrm{p}<0.05)$ antara kemajuan sperma dan kepadatan selnya. Kesimpulannya, DMSO memberikan perlindungan yang terbaik ke atas sel sperma S. olivacea, tetapi keberkesanan DMSO sebagai krayoprotektan dipengaruhi oleh ketumpatan sperma yang digunakan.

Kata kunci: Kepadatan sperma; ketam bakau; krioprotektan; Scylla olivacea; spermatozoa

\section{INTRODUCTION}

In Malaysia, mud crab especially genus Scylla is commercially important and their mass culture was considered to continue to grow in the future (Azra \& Ikhwanuddin 2015). Capture of wild crabs is an important source of income for small-scale fishermen throughout the Asia-Pacific region (Lindner 2005). The increasing market price of mud crabs in Malaysia has encouraged many coastal fishing communities to initiate culture trials in floating cages and more recently in pen enclosure in mangrove forests (Tan 1999). Mud crabs are increasingly known to be a popular species for aquaculture
(Ikhwanuddin et al. 2014a). Exploitation of the world's mud crabs has increased dramatically over the last 30 years (Lindner 2005), more so for the mud crab, Scylla spp. than the blue swimmer crab, Portunus spp. Fiedler and Allan (2004) expressed concern that further expansion of mud crab aquaculture would require an alternative source of seed, as the maximum sustainable yield from wild stocks has been reached at some locations. Currently, aquaculture production of mud crabs relies on wild-caught seed for stocking ponds, as larval rearing is becoming popular due to the difficulty of obtaining wild-caught seed (Quinitio \& Parado-Estapa 2008; Shelley \& Lovatelli 2011; Tan 1999). 
Good quality sperm via spermatophore preservation would provide an alternative source of reliable and high quality spermatophores. Preservation of spermatophores for long periods would be a further advantage for future breeding programs (Memon et al. 2012a, 2012b, 2011). The current size and quantities of crab 'seed' caught by fishermen are not sufficient to meet demand (Kosuge 2001). Off season spawning can be induced in cultured species, but the techniques are cost intensive. With the availability of cryopreserved mud crab sperm throughout the year, manipulation of the spawning season could be restricted to only female crabs (Suquet et al.2000). Despite the increasing interest in mud crab farming, very little information exists on mud mud crab breeding in detailed (Noorbaiduri et al. 2014; Quinitio \& Parado-Estapa 2008; Shelley \& Lovatelli 2011). To date, very little research has been done on the spermatozoa cryopreservation of the mud crab (except by Bhavanishankar \& Subramoniam (1997) and Jeyalectumie \& Subramoniam (1989) for Scylla serrata), especially Scylla olivacea. The objectives of this study were to determine the effect of different cryoprotectants and sperm densities for long term storage of the spermatozoa of orange mud crab, S. olivacea.

\section{MATERIALS AND METHODS}

The study was conducted at the Institute of Tropical Aquaculture (AKUATROP), Universiti Malaysia Terengganu. Mature males of $S$. olivacea (7-12 cm in carapace width) were obtained from Setiu, Terengganu, Malaysia $\left(5^{\circ} 20^{\prime}\right.$ N ; $\left.102^{\circ} 36^{\prime \prime} \mathrm{E}\right)$. All of the crabs were held for 3 to 5 days in a rectangular fiberglass holding tank with aerated seawater and $5 \mathrm{~cm}$ thick sand substrate at the bottom of the holding tank. Seawater salinity and temperature in the maturation tank was maintained at $28-30 \mathrm{ppt}$ and $28-31^{\circ} \mathrm{C}$ under natural photoperiod of approximately 12-h light: 12-h dark. Natural food (trash fishes) at $5 \%$ biomass was given as food daily in the evening $(20: 00 \mathrm{~h})$ and $100 \%$ seawater was changed daily according to the study by Muhd-Farouk et al. (2014). Body weight (BW) and carapace width (CW) of the crabs were measured before dissection. A styrofoam box was filled with ice to keep the sperm in good condition. The vas deferens containing seminal plasma and vesiculate spermatophores were removed based on the study by Ikhwanuddin et al. (2014b). The samples were used for cryopreservation studies.

The Ca-Fsaline $(21.63 \mathrm{~g} \mathrm{NaCl}, 1.12 \mathrm{~g} \mathrm{KCl}, 0.53 \mathrm{~g}$ $\mathrm{H}_{3} \mathrm{BO}_{3}, 0.19 \mathrm{~g} \mathrm{NaOH}$ and $4.93 \mathrm{~g} \mathrm{MgSO}_{4} .7 \mathrm{H}_{2} \mathrm{O}$ in $1 \mathrm{~L}$ sterile distilled water (adjusted to $\mathrm{pH} 7.4$ with $1 \mathrm{NHCl}$ )) was prepared as the extender medium (Bart et al. 2006; Memon et al. 2012d). The extender was prepared one day before the collection of samples and stored in the refrigerator. Three different cryoprotectants: DMSO, glycerol and methanol were prepared one day before sample collection. Each cryoprotectant solution was prepared to a final concentration of $5.0 \%(\mathrm{v} / \mathrm{v})$ using sterile calcium-free saline (Ca-Fsaline) as the extender medium.
Spermatozoa were obtained from spermatophores in the vas deferens and placed in pre-cooled $\left(4^{\circ} \mathrm{C}\right) \mathrm{Ca}-\mathrm{F}$ saline. Firstly, the spermatophores were extruded slightly by forceps point from vas deferens in $\mathrm{Ca}-\mathrm{F}$ saline. The suspension was then ground using a glass homogenizer in an ice-bath to form a spermatophores homogenate which was later settled for $10 \mathrm{~min}$. The supernatant was centrifuged at $310 \mathrm{rpm}$ for $10 \mathrm{~min}$ at $4^{\circ} \mathrm{C}$ to separate the spermatozoa suspension and to precipitate the spermatophore fragments. The supernatant was then further centrifuged at $400 \mathrm{rpm}$ for $5 \mathrm{~min}$ to precipitate the spermatophore fragments. The spermatozoa suspension was further centrifuged at $1133 \mathrm{rpm}$ for $10 \mathrm{~min}$ at the same temperature to obtain a concentrated spermatozoa pellet. Sperm suspension was then pipetted into a $1.8 \mathrm{~mL}$ cryovial. After $30 \mathrm{~min}$ equilibration $\left(4^{\circ} \mathrm{C}\right)$, cryovials were then arranged in a cryobox, kept at $0^{\circ} \mathrm{C}(3 \mathrm{~min})$ and then transferred to $-20^{\circ} \mathrm{C}(14 \mathrm{~min})$ and $-80^{\circ} \mathrm{C}(43 \mathrm{~min})$ (modified from Kang et al. (2009) and Memon et al. (2012b)). After that cryovials were arranged on cryocanes and slowly immersed completely in liquid nitrogen (LN). The samples were kept in LN for 30 days (Memon et al. 2012b). On day 30 , thawing was done by immersing the cryovial in a water bath at $30^{\circ} \mathrm{C}$ for $2 \mathrm{~min}$ (Bart et al. 2006; Memon et al. 2012b). After thawing, the samples were examined under the electron microscope.

The $0.5 \%$ eosin solution was prepared by dissolving $0.5 \mathrm{~g}$ of eosin in $100 \mathrm{~mL}$ distilled water, whereas the $1.0 \%$ nigrosin solution was prepared by dissolving $1 \mathrm{~g}$ nigrosinin in $100 \mathrm{~mL}$ distilled water (modified from Memon et al. (2011)). On day 30 , the sperm viability was calculated and the sperm density was then been calculated. To evaluate sperm viability, the eosin-nigrosin staining method was used. A smear was prepared by transferring one drop $(5 \mu \mathrm{L})$ of thawed seminal plasma with one drop $(5 \mu \mathrm{L})$ of $0.5 \%$ eosin and 2 drops $(10 \mu \mathrm{L})$ of $1.0 \%$ nigrosin. The slides after being air-dried were examined under a light microscope (400× magnification). The dead sperm cells were stained pink and live sperm cells remain unstained against the dark background of nigrosin. Unstained and dead sperm cells will be expressed as the percentage of total sperm count. All results were tested for significance using two way analysis of variance (ANOVA) to determine the sperm viability in each cryoprotectant and interactions between the cryoprotectant and its sperm density. Differences were considered significant at $p<0.05$. Data in percentage was arcsine transformed before analysis. Statistical analysis was performed using the aid of Microsoft Office Excel version 2007.

\section{RESULTS AND DISCUSSION}

\section{SPERM DENSITY}

At the earlier of experiments, the total sperm cell density was determined by using a haemacytometer under the electron microscope $400 \times$ magnifications. Due to 
low quantity of sperm cells obtained from each crab, spermatozoa of five crabs were combined to carry out experiments for each treatment at two densities, which were $10^{6}$ and $10^{8}$ cells $/ \mathrm{mL}$. For glycerol, from the total density of sperm cells was $2.631 \times 10^{9}$ cells $/ \mathrm{mL}$ whereas for DMSO and methanol, the total density of the sperm cells was $3.085 \times 10^{9}$ and $2.857 \times 10^{9}$ cells $/ \mathrm{mL}$, respectively. The sperm cells were then diluted to a density of $5.000 \times$ $10^{6}$ and $5.000 \times 10^{8}$ cells $/ \mathrm{mL}$ and preserved in the liquid nitrogen. For glycerol, DMSO and methanol which were set with density of $10^{6}$ cells $/ \mathrm{mL}$, the results calculated on day 30 were $4.228 \times 10^{7} \pm 1.647 \times 10^{7}, 5.666 \times 10^{7} \pm 3.813$ $\times 10^{7}$ and $7.021 \times 10^{7} \pm 1.508 \times 10^{7}$ cells $/ \mathrm{mL}$, respectively. Meanwhile, the experiments for the density of $10^{8}$ cells/ $\mathrm{mL}$, the results obtained were $4.902 \times 10^{8} \pm 1.033 \times 10^{8}$, $6.089 \times 10^{8} \pm 2.753 \times 10^{8}$ and $1.916 \times 10^{9} \pm 4.972 \times 10^{8}$ cells $/ \mathrm{mL}$, respectively. The sperm density before dilution was between $2.631 \times 10^{9}$ to $3.085 \times 10^{9}$ cells $/ \mathrm{mL}$. It was then diluted to the density of $5.000 \times 10^{6}$ and $5.000 \times 10^{8}$ cells $/ \mathrm{mL}$. At the end of the experiment, sperm density was slightly higher than the value set before. There are few possibilities that can lead to this slight increase in sperm density. Spermatophores were observed while counting for the sperm viability on day 30 . The sperm cells may be spontaneously released from the spermatophores due to swelling of spermatophores cell wall after settlement in calcium-free artificial seawater (Kang et al. 2009). The different of sperm density prepared on the earlier experiment and at the end of the experiment might occur due to over counting. There are difficulties in observing the sperm cells under the microscope as the cell size is too small although high magnification was used. The original concentrated sperm density before dilution was between $2.631 \times 10^{9}$ to $3.085 \times 10^{9}$ cells $/ \mathrm{mL}$. The density is too high which makes the sperm cells immovable and obtain oxygen. This can further lead to different result obtained from an experiment (Scott \& Baynes 1980). Withler (1982) stated that several combinations of extenders and cyroprotectants might be effective in cryopreservation. Laboratory observations of sperm cells are much smaller than the fish sperms cells. Bhavanishankar and Subramoniam (1997) have cryopreserved the isolated spermatozoa of $S$. serrata with concentration of $\sim 10^{6}$ cells/ $\mathrm{mL}$. From previous study, glycerol and DMSO offered as cryoprotection to mud crab, $S$. serrata sperm diluted to a concentration of $\sim 10^{6}$ cells $/ \mathrm{mL}$, at concentrations ranging from 5.0 to $15.0 \% \mathrm{v} / \mathrm{v}$. Post-thaw survival was highest with $12.5 \%$ glycerol at a cooling rate of $-5^{\circ} \mathrm{C} \min \pm 1$ (Bhavanishankar \& Subramoniam 1997). Memon et al. (2012b) reported that Banana shrimp, Penaeus merguiensis sperm viability glycerol produced sperm viability of $>70 \%$ at 5,10 and $15 \%$ concentrations for 5 min exposure time at room temperature $\left(25^{\circ} \mathrm{C}\right)$. In this experiment, DMSO gave the best result in protecting the sperm cells with the density of $10^{8}$ cells $/ \mathrm{mL}$. However, in the density of $10^{6}$ cells $/ \mathrm{mL}$, methanol provided better protection compared with DMSO and glycerol. In a previous study by Memon et al. (2012b), P. merguiensis sperm viability of $>80 \%$ was observed with
DMSO at 5 or $10 \%$ for 5 and 15 min of exposure time. Compared with combination of DMSO and trehalose, DMSO may be more toxic to the sperm cells when used alone. Methanol which is least toxic cryoprotectant to sperm of S. serrata than DMSO, ethylene glycol (EG) and glycerol at three physiological temperatures $\left(15,23\right.$ and $\left.30^{\circ} \mathrm{C}\right)$, failed to provide effective cryoprotection (Bhavanishankar \& Subramoniam 1997). Memon et al. (2012b) stated that $P$. merguiensis percentage of viable sperm in methanol was $>60 \%$ for 5,15 and 30 min exposure. In contrast, in this study, methanol showed the least deteriorating effect among other cryoprotectants when sperm were cryopreserved in density of $10^{6}$ cells $/ \mathrm{mL}$. However, the mortality percentage which is $20.809 \pm 3.557 \%$ is considered high if compared with other experiment results. The research suggested that glycerol could have speciesspecific effects on spermatozoa. This argument can be applied more generally to other permeating cryoprotectants such as DMSO, ethylene glycol and methanol as well (Holt 2000). Other than that, there are other factors which affect the effectiveness of cryoprotectants such as the cooling rate, concentration of cryoprotectant, extender, equilibrium rate, thawing rate and much more. The rate of cooling is a critical variable during cryopreservation. The cooling rate in present study was $1^{\circ} \mathrm{C} \mathrm{min}^{-1}$. However, the cooling rate was done manually and not by using the temperature controller. Therefore, it might have a bit influence on the results obtained. Each type of cell exhibiting optimal cooling rate for maximum post-thaw survival (Scott \& Baynes 1980). Meryman (1974) stated the importance of selecting an optimal cooling rate for cryo survival. Slow freezing rates generate extracellular ice growth. This results in injury due to increase in concentration of solutes, leading to solution effects, as water is frozen out of solution. On the other hand, fast freezing rates increase the probability of intracellular ice formation leading to cryo-injuries. Therefore, some of the results obtained through the experiment may differ with results obtained from previous study.

\section{PERCENTAGE VIABILITY OF FRESH SPERM, EFFECTS OF} CRYOPROTECTANTS AND DENSITIES ON SPERM VIABILITY

From observation, spermatozoa released from the spermatophores situated in the vas deferens appeared uniformly spherical in shape (Ikhwanuddin et al. $2014 b)$. The results showed that the percentages of fresh spermatozoa were $88.242 \pm 7.009 \%$ (glycerol), $85.909 \pm 7.214 \%$ (DMSO) and $92.038 \pm 3.118 \%$ (methanol) (Table 1). The mean mortality of fresh spermatozoa was $11.270 \pm 3.094 \%$, which showed that the spermatozoa were initially of good quality and could be used for subsequent experiments. Statistical evaluation suggested that the resistance to cryoprotectant toxicity differed in response to different cryoprotectants and densities (Table 2). On day 30, there was drastic decrease in percentage of sperm viability for glycerol and DMSO within the density of $10^{6}$ cells $/ \mathrm{mL}$. Sperm cells which had been cryopreserved in glycerol 
after 30 days showed sperm mortality of $25.300 \pm 5.195 \%$ (Table 2; Figure 1) and from $88.242 \pm 7.009 \%$ in control to $62.941 \pm 5.195 \%$ (Table 1 ). DMSO also showed no mortality different with results obtained from glycerol which was $25.227 \pm 3.608 \%$ (Table 2 ). The sperm viability dropped from $85.909 \pm 7.214 \%$ in control to $60.682 \pm 3.608 \%$ at the end of the experiment (Table 1). Sperm cells in methanol had the highest survival with the least mortality of $20.809 \pm 3.557 \%$ (Table 2). There was no significant difference $(p=0.38 ; p>0.05)$ among the cryoprotectants in sperm viability for density of $10^{6}$ cells $/ \mathrm{mL}$. All spermatozoa cyropreserved in three different cryoprotectants with the density of $10^{8}$ cells $/ \mathrm{mL}$ yielded better result compared to those cyropreserved with the density of $10^{6}$ cells $/ \mathrm{mL}$. DMSO was the least toxic of all the cryoprotectants examined (Table 2), with the least mortality of $6.438 \pm 3.520 \%$. It was then followed by $9.104 \pm 4.311 \%$ (glycerol) and
$11.789 \pm 1.941 \%$ (methanol). One-way analysis of variance (ANOVA) showed that there was no significant difference $(p=0.25 ; p>0.05)$ of sperm viability among the three cryoprotectants in spermatozoa density of $10^{8}$ cells $/ \mathrm{mL}$. Spermatozoa in two different cryoprotectants with the highest density $10^{8}$ cells $/ \mathrm{mL}$ had the highest survival rate. The mean mortality for cryopreserved spermatozoa with density $10^{8}$ cells $/ \mathrm{mL}$ in glycerol, DMSO and methanol were $9.104 \pm 4.311 \%, 6.438 \pm 3.520 \%$ and $11.789 \pm 1.941 \%$, respectively. The increase in sperm density increased the overall survival percentage in spermatozoa (Table 2). The density of $10^{6}$ cells/mL showed the least survival with the highest mortality of $25.300 \pm 5.195 \%$ for glycerol. Overall, the statistical analysis showed that there were no significant difference ( $p=0.70 ; p>0.05)$ between different cryoprotectants. Besides, different density showed a significant different $(p=0.00 ; p<0.05)$ in sperm viability.

TABLE 1. Percentage of live sperm cells (\%) of S. olivacea for control and day 30 in cryoprotectants: Glycerol, DMSO and methanol at a density of $10^{6}$ cells $/ \mathrm{mL}$ and $10^{8}$ cells $/ \mathrm{mL}$

\begin{tabular}{ccccccc}
\hline $\begin{array}{c}\text { Cell density } \\
(\text { cells } / \mathrm{mL})\end{array}$ & \multicolumn{2}{c}{ Glycerol } & \multicolumn{2}{c}{$\begin{array}{c}\text { Cryoprotectants } \\
\text { DMSO }\end{array}$} \\
\hline & Control & Day 30 & Control & Day 30 & Control & Day 30 \\
$10^{6}$ & $88.24 \pm 7.01$ & $62.94 \pm 5.19$ & $85.91 \pm 7.21$ & $60.68 \pm 3.61$ & $92.04 \pm 3.12$ & $71.23 \pm 3.56$ \\
& - & & - & & - & \\
$10^{8}$ & & $79.14 \pm 4.31$ & & $79.47 \pm 3.52$ & & $80.25 \pm 1.94$ \\
\hline
\end{tabular}

TABLE 2. Percentage mortality of sperm cell (\%) of S. olivacea, mean \pm standard deviation $($ mean $\pm \mathrm{sd})(n=3)$ on day 30 in cryoprotectants: Glycerol, DMSO and methanol at a density of $10^{6}$ cells $/ \mathrm{mL}$ and $10^{8}$ cells $/ \mathrm{mL}$

\begin{tabular}{cccc}
\hline $\begin{array}{c}\text { Density } \\
(\text { cells } / \mathrm{mL})\end{array}$ & Glycerol & $\begin{array}{c}\text { Cryoprotectants } \\
\text { DMSO }\end{array}$ & Methanol \\
\hline $10^{6}$ & $25.30 \pm 5.195 \%$ & $25.23 \pm 3.608 \%$ & $20.81 \pm 3.557 \%$ \\
$10^{8}$ & $9.10 \pm 4.311 \%$ & $6.44 \pm 3.520 \%$ & $11.79 \pm 1.941 \%$ \\
\hline
\end{tabular}

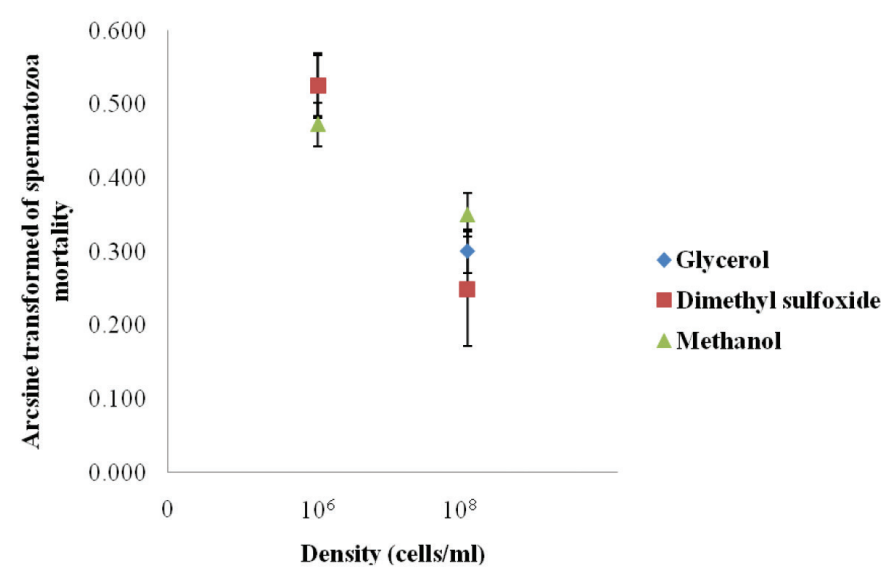

FIGURE 1. Sperm mortality of S. olivacea. Arcsine transformation mean \pm standard deviation (mean $\pm \mathrm{sd})(n=3)$ on day 30 in cryoprotectants: Glycerol, DMSO and methanol at a density of density of $10^{6}$ cells $/ \mathrm{mL}$ and $10^{8}$ cells $/ \mathrm{mL}$ 
Unsuccessful attempts using eosin-nigrosin staining for sperm viability assessment had led to the use of observation on sperm activity such as vibration and rotation. Eosinnigrosin staining used for staining the dead spermatophores of P. merguiensis (Memon et al. 2012b) showed selective differences in membrane permeation in the present study and hence had been discontinued. Literature showed that spermatozoa of $S$. serrata are non-motile, therefore their viability have been assessed by inducing them to undergo acrosome reaction (Bhavanishankar \& Subramoniam 1997). In this experiment, however, S. olivacea crab sperm did not show active movement compared to other organisms' sperm cells which moving from a place to another for far distance. The sperm cells of $S$. olivacea showed that they vibrated and rotated in a static position. Therefore, these observations have been used to assess the sperm viability.

\section{CONCLUSION}

The results showed that DMSO gave the best protection to sperm cells of $S$. olivacea. The effectiveness of DMSO as a cryoprotectant was influenced by the density of sperm used. However, future studies should include successful fertilization and hatching percentage of the most effective cryoprotectant used. The best result in sperm viability was obtained from 5.0\% DMSO with a density of $10^{8}$ cells/ $\mathrm{mL}$. This was followed by glycerol and methanol with the same cell density.

\section{ACKNOWLEDGEMENTS}

This study was funded by the Ministry of Education (KPM), Malaysia under Niche Research Grant Scheme (NRGS, 2013-2018) - Improving the Health of Setiu Wetlands Ecosystem and Productivity of Crustacean Resources for Livelihood Enhancement (Vote No. 53131). Our great appreciation is directed to Institute of Tropical Aquaculture, Universiti Malaysia Terengganu and all people who were involved directly or indirectly in this study.

\section{REFERENCES}

Azra, M.N. \& Ikhwanuddin, M. 2015. A review of maturation diets for mud crab genus Scylla broodstock: Present research, problems and future perspective. Saudi Journal of Biological Science. In press. DOI: http://dx.doi.org/10.1016/j. sjbs.2015.03.011.

Bart, A.N., Choosuk, S. \& Thakur, D.P. 2006. Spermatophore cryopreservation and artificial insemination of black tiger shrimp, Penaeus monodon (Fabricius). Aquaculture Research 37(5): 523-528.

Bhavanishankar, S. \& Subramoniam, T. 1997. Cryopreservation of spermatozoa of the edible mud crab Scylla serrata (Forskal). Journal of Experimental Zoology 277(4): 326-336.

Fiedler, D. \& Allan, G. 2004. Executive summary and recommendations. In Mud Crab Aquaculture in Australia and Southeast Asia, Proceedings of the ACIAR Crab Aquaculture Scoping Study and Workshop, edited by Allan, G. \& Fiedler.
April 28-29, 2003. Joondooburri Conference Centre, Bribie Island, Australia. pp. 7-9.

Holt, W.V. 2000. Basic aspects of frozen storage of semen. Animal Reproduction Sciences 62(1-3): 3-22.

Ikhwanuddin, M., Noor Baiduri, S., Wan Norfaizza, W.I. \& Abol-Munafi, A.B. 2014a. Effect of water salinity on mating success of orange mud crab, Scylla olivacea (Herbst, 1796) in captivity. Journal of Fisheries and Aquatic Science 9(3): 134-140.

Ikhwanuddin, M., Muhd-Farouk, H., Memon, A.J., Wendy, W. \& Abol-Munafi, A.B. 2014b. Sperm viability assessment over elapsing time maintained at $2^{\circ} \mathrm{C}$ of orange mud crab, Scylla olivacea (Herbst, 1796). Pakistan Journal of Biological Sciences 17(9): 1069-1073.

Jeyalectumie, C. \& Subramoniam, T. 1989. Cryopreservation of spermatophores and seminal plasma of the edible crab Scylla serrata. Biological Bulletin 177(2): 247-253.

Kang, X.J., Li, G.L., Mu, S.M., Guo, M.S. \& Ge, S.Q. 2009. Acrosome reaction of Chinese mitten-handed crab Eriocheir sinensis (Crustacea: Decapoda) spermatozoa: Promoted by long-term cyopreservation. Aquaculture 295(3-4): 195-199.

Kosuge, T. 2001. Brief assessment of stock of mud crabs Scylla spp. in Matang mangrove forest, Malaysia and proposal for resources management. JARQ-Japan Agricultural Research Quarterly 25(2): 145-148.

Lindner, B. 2005. Impacts of mud crab hatchery technology in Vietnam. Impact Assessment Series Report No. 36. Australian Centre for International Agricultural Research, Australia. pp. 1-68.

Memon, A.J., Ikhwanuddin, M. \& Abol-Munafi, A.B. 2012a. Spermatophore Cryopreservation of Banana Shrimp, Penaeus merguiensis. Saarbrucken, Germany: LAMBERT Academic Publishing (LAP). p. 236.

Memon, A.J., Talpur, A.D., Fariddudin, M.O., Safiah, J., AbolMunafi, A.B. \& Ikhwanuddin, M. 2012b. Optimization of spermatophores cryopreservation protocol of banana shrimp Penaeus merguiensis (De Man, 1888). Journal of Animal and Veterinary Advances 11(10): 1688-1704.

Memon, A.J., Ikhwanuddin, M., Talpur, A.D., Fariddudin, M.O., Safiah, J. \& Abol-Munafi, A.B. 2011. Assessment of sperm viability, determination fertilization capacity and hatching rate by artificial insemination of banana shrimp, Penaeus merguiensis (De Man, 1888). Research Journal of Applied Sciences 6(3): 174-178.

Meryman,H.T. 1974. Freezing injury and its prevention in living cells. Annual Review of Biophysics and Bioengineering 3: 341-363.

Muhd-Farouk, H., Abol-Munafi, A.B., Jasmani, S. \& Ikhwanuddin, M. 2014. Effect of steroid hormones $17 \alpha$-hydroxyprogesterone and $17 \alpha$-hydroxypregnenolone on ovary external morphology of orange mud crab, Scylla olivacea. Asian Journal of Cell Biology 9(1): 23-28.

Noorbaiduri, S., NurulAkmal, S. \& Ikhwanuddin, M. 2014. Mating success of hybrid trials between two mud crab species, Scylla tranquebarica and Scylla olivacea. Journal of Fisheries and Aquatic Science 9(2): 85-91.

Quinitio,E.T. \& Parado-Estepa, F.D. 2008. Biology and Hatchery of Mud Crabs Scylla spp. Aquaculture and Extension Manual. Southeast Asian Fisheries Development Center, Aquaculture Department. p. 39.

Scott, A.P. \& Baynes, S.M. 1980. A review of the biology, handling and storage of salmonid spermatozoa. Journal of Fish Biology 17(6): 707-739. 
Shelley, C. \& Lovatelli, A. 2011. Mud Crab Aquaculture - A Practical Manual. Food and Agriculture Organization of the United Nations (FAO), Fisheries and Aquaculture Technical Paper. No. 567. Rome, FAO. p. 78.

Suquet, M., Dreanno, C., Fauvel, C., Cosson, J. \& Billard, R. 2000. Cryopreservation of sperm in marine fish. Aquaculture Research 31(3): 231-243.

Tan, E.S.P. 1999. Malaysian crab research. In Mud Crab Aquaculture and Biology, Proceedings of an International Scientific Forum, Australian Centre for International Agricultural Research, edited by Keenen, C.P. \& Blackshaw, A. April 21-24, 1997. Darwin, Australia. pp. 25-26.

Withler, F.C. 1982. Cryopreservation of spermatozoa of some freshwater fishes cultured in South and Southeast Asian. Aquaculture 26(3-4): 395-298.

Mhd Ikhwanuddin* \& Safiah Jasmani Institute of Tropical Aquaculture, Universiti Malaysia Terengganu 21030 Kuala Terengganu, Terengganu Darul Iman Malaysia
Teng Phei Yin

School of Marine Science and Environment

Universiti Malaysia Terengganu

21030 Kuala Terengganu, Terengganu Darul Iman

Malaysia

Abdul Jabbar Menon

Directorate of Fisheries Inland Hyderabad

Live Stock \& Fisheries Department, Government of Sindh Pakistan

Ambok Bolong Abol-Munafi

School of Fisheries and Aquaculture Sciences

Universiti Malaysia Terengganu

21030 Kuala Terengganu, Terengganu Darul Iman

Malaysia

*Corresponding author; email: ikhwanuddin@umt.edu.my

Received: 12 August 2014

Accepted: 26 May 2015 